\title{
Penile metastasis as a first sign of lung cancer
}

This article was published in the following Dove Press journal:

International Medical Case Reports Journal

14 July 2009

Number of times this article has been viewed

\section{Sevket Ozkaya' \\ Serhat Findik ${ }^{2}$ \\ Atilla G Atici²}

'Samsun Chest Diseases and Thoracic Surgery Hospital, Samsun, Turkey;

${ }^{2}$ Department of Pulmonary Medicine, Faculty of Medicine, Ondokuz Mayis University, Kurupelit, Samsun, Turkey
Correspondence: Serhat Findik

Associate Professor, Department of

Pulmonary Medicine, Faculty of Medicine,

Ondokuz Mayis University, Kurupelit,

Samsun, Turkey

Tel +90 5325868869

Email serhatfindikl@yahoo.com
Abstract: Lung cancer does not generally produce any symptoms at the early stages and it rapidly metastasizes. Although lung cancer has a potential of metastasis to all organs and tissues, metastasis to the penis from lung cancer is very rare. We present a case with a penile lesion as the first sign of lung cancer.

Keywords: lung cancer, metastasis, penis

\section{Introduction}

Lung cancer is currently the leading cause of cancer death throughout the world. Lung cancer does not generally produce any symptoms at the early stages and it rapidly metastasizes. Although lung cancer has a potential of metastasis to all organs and tissues, the main sites of metastases are bones, liver, brain, and adrenal glands. Although the penis has a very rich vascularization, metastasis to the penis is very rare. The penis is usually affected by local infiltration of carcinomas of adjacent organs such as prostate, rectum, colon, and bladder.

Penile metastasis of lung cancer has been rarely reported, that is, where all patients had been diagnosed with lung cancer before penile metastasis. ${ }^{1}$ To our knowledge, there is no paper reporting a penile lesion as a first sign of lung cancer.

\section{Case report}

A 55-year-old man was seen in the urology clinic of Samsun Chest Diseases and Thoracic Surgery Hospital because of a painful lesion on his penis for three months. He also complained of effort dyspnea for two years. He denied fever, sputum production, malaise, and anorexia with weight loss. He was a retired officer. His medical history was noteworthy of a 35 pack-year smoking history and he was circumcised when he was seven years old. There were no other significant features in both his self-reported history and family history.

On physical examination, the patient appeared well. Vital signs were normal. He had a barrel chest. There was a reduction of respiratory sounds on both lungs with hyperresonance on percussion and decreased tactile fremitus. Grade V finger clubbing was present. Urologic examination revealed an irregularly shaped, ulcerous lesion of $2 \times 2.5 \mathrm{~cm}$ in diameter on the glans penis (Figure 1). The remainder of the findings from examination were within normal limits.

A chest roentgenogram demonstrated a solitary pulmonary nodule in the right middle zone and bilateral hyperlucency with hyperinflation. 


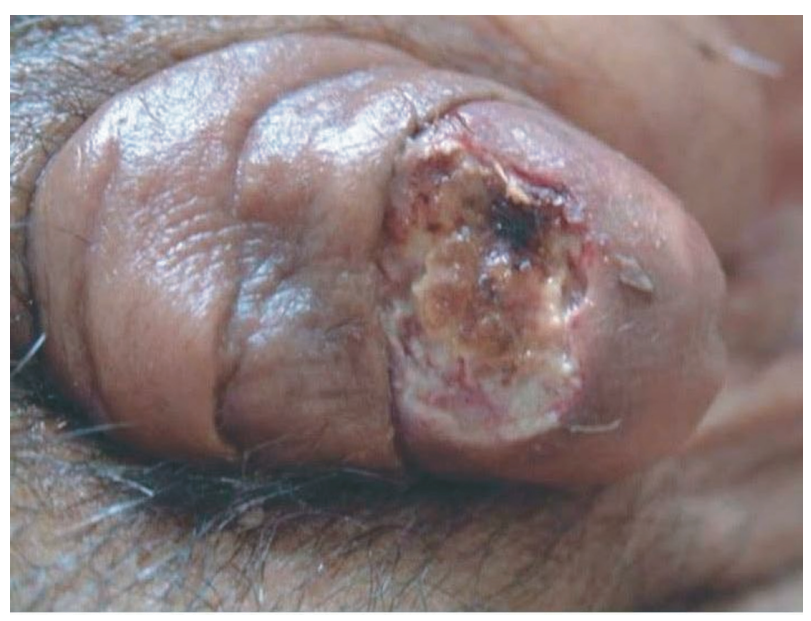

Figure I An ulcerous lesion of $2 \times 2.5 \mathrm{~cm}$ in diameter on glans penis.

Complete blood count (CBC) and whole blood chemistry values were within normal limits. Erythrocyte sedimentation rate was $100 \mathrm{~mm}$ per hour. Levels of prostatic acid phosphatase and prostate-specific antigen were normal.

Chest computed tomography (CT) scan revealed diffuse panlobular emphysema and a solitary pulmonary nodule, $2 \times 2.5 \mathrm{~cm}$ in diameters with speculated borders, on the lateral segment of the middle lobe of the right lung (Figure 2). Mediastinum and pleura were normal. Biopsy was taken from the penile lesion and its histopathologic examination was reported as epidermoid carcinoma (Figure 3).

Fiberoptic bronchoscopic examination was normal. CT-guided transthoracic biopsy from the nodule was performed and its histopathologic examination was reported as epidermoid carcinoma (Figure 4). Staging procedures

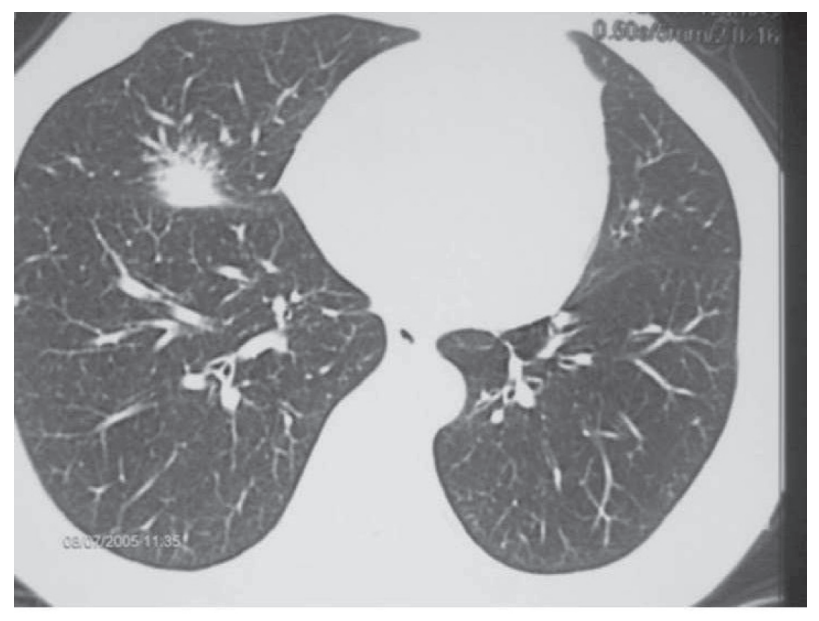

Figure 2 Chest computed tomography scan revealed diffuse panlobular emphysema and a solitary pulmonary nodule, $2 \times 2.5 \mathrm{~cm}$ in diameter with speculated borders, on the lateral segment of the middle lobe of the right lung.

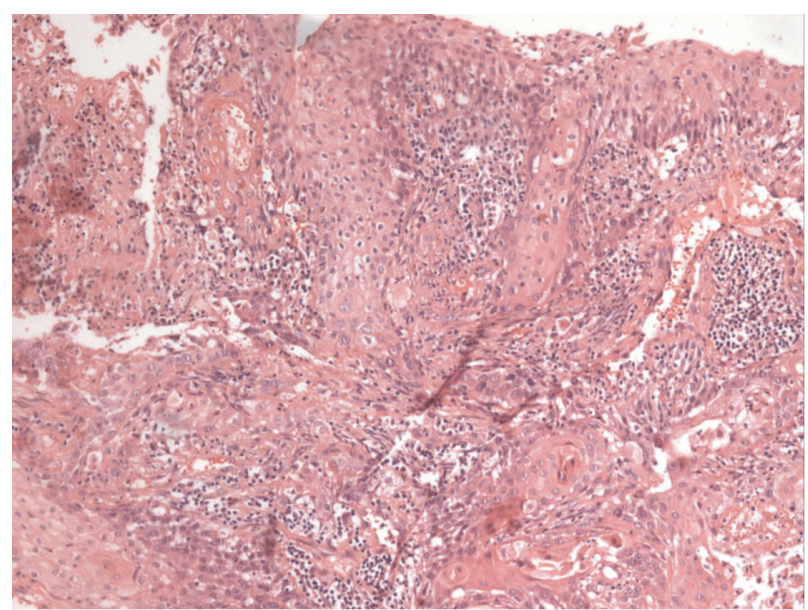

Figure 3 Biopsy was taken from the penile lesion and its histopathologic examination was reported as epidermoid carcinoma.

including CT scans of cranium, abdomen, and pelvis, and bone scintigraphy were performed, which showed normal results. As a result of these findings, the patient was diagnosed with a penile metastasis of lung cancer. We offered radical treatment to the patient, but he refused and wanted to be discharged. The patient died at the sixth month after diagnosis.

\section{Discussion}

Lung cancer symptoms may range from none to such problems as cough, hemoptysis, dyspnea, fever, and hoarseness. Only $5 \%$ to $10 \%$ of patients are asymptomatic at discovery, and $15 \%$ of patients have extrapulmonary symptoms as the first clue to the diagnosis. ${ }^{2}$ Lung cancer has a potential of metastasis to all organs and tissues, but the penis is a very

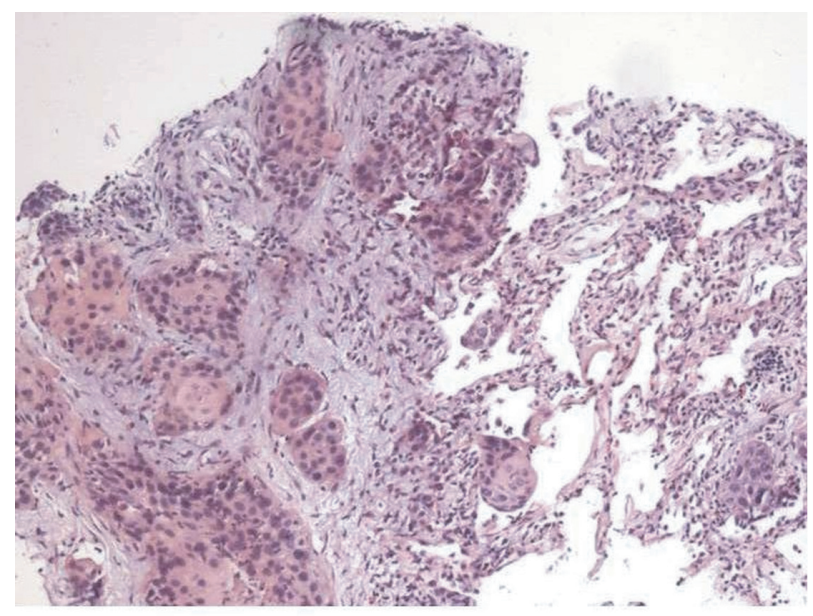

Figure 4 Computed tomography-guided transthoracic biopsy from the nodule was performed and its histopathologic examination was reported as epidermoid carcinoma. 
unusual site for its metastasis. And penile metastasis of lung cancer has been rarely reported where all patients had been diagnosed with lung cancer before penile metastasis. ${ }^{1}$

There were 18 cases with penile metastasis of lung cancer in the literature. ${ }^{1}$

Histopathologic types of lung cancer were as follows: 14 patients, epidermoid cancer; one patient, small cell lung cancer; one patient, adenocarcinoma; one patient, large cell carcinoma; and one patient, epithelial carcinoma. The common feature of these patients was that penile metastasis was detected after lung cancer had been diagnosed. In spite of the fact that these patients had priapismus, urinary retention, and mass in the penis, all these patients had been diagnosed with lung cancer before penile metastasis. On the contrary, our patient had a painful lesion on his glans penis as an initial symptom with three months of duration before he was diagnosed with lung cancer.

There were two possibilities for diagnosis of the patient; primary penile carcinoma metastasizing to lung or primary lung cancer metastasizing to the penis because of the same histopathology: epidermoid carcinoma of both lung and penis. We thought the clinical picture of the patient was much more consistent with primary lung cancer metastasizing to the penis.

Firstly, the most important etiologic factor for primary penile carcinoma is the presence of the foreskin. ${ }^{3}$ Therefore, protection against this malignancy is apparently conferred by circumcision, the incidence among different population groups varies widely throughout the world. Carcinoma of the penis is virtually unknown among Jews, in whom ritual circumcision is performed in the first days of life. It is extremely rare among Moslems, in whom circumcision is performed before the tenth year of life. In regions of the world where circumcision is not routinely practiced, carcinoma of the penis is correspondingly more common. ${ }^{4}$ As our patient had been circumcised when he was seven years old, he did not have the main risk factor for primary penile carcinoma. And secondly, primary penile carcinoma is a slowly growing, locally metastasizing lesion, such as pelvic organs, inguinal and iliac lymph nodes, which often has been present for a year or more before it is brought to medical attention the initial metastasis locations for the primary penis tumors are pelvic organs and lymph glands. Our patient reported that he had noticed the penile lesion three months prior to presentation at our hospital.

Neither physical examination nor radiologic examination did show any abnormality related to pelvic organs and regional lymph nodes.

Since both lung cancer, solitary pulmonary nodule, and its solitary metastasis, penis, were within surgical limits, and there was no other organ involvement, surgical approach for both would be the best approach. But because the patient refused and wanted to be discharged, only palliative treatment could be given.

In conclusion, the penis, although exceedingly rare, may be also a site for metastasis of lung cancer and its involvement may be a presenting sign for lung cancer.

\section{Disclosure}

The authors report no conflicts of interest in this work.

\section{References}

1. Fujimoto N, Hiraki A, Ueoka H, Harada M. Metastasis to the penis in a patient with squamous cell carcinoma of the lung with a review of reported cases. Lung Cancer. 2001;34:149-152.

2. Alberts WM. Lung Cancer. In: Levine SM, Alberts WM, Ashkin D, et al. editors. ACCP Pulmonary Board Review Course Syllabus. Northbrook, IL: American College of Chest Physicians; 2006. p. 173-194.

3. Pettaway CA, Dinney CPN. Urologic and male genital cancer. In: Lenhard RE, Osteen RT, Gansler T, editors. Clinical Oncology. 2nd ed. Atlanta, GA: American Cancer Society; 2000. p. 435-454.

4. Persky L, de Kernion J. Carcinoma of the penis. CA Cancer J Clin 1986;36:258-273.
International Medical Case Reports Journal

\section{Publish your work in this journal}

The International Medical Case Reports Journal is an international, peer-reviewed open-access journal publishing original case reports from all medical specialties. Previously unpublished medical posters are also accepted relating to any area of clinical or preclinical science. Submissions should not normally exceed 2,000 words or

\section{Dovepress}

4 published pages including figures, diagrams and references. The manuscript management system is completely online and includes a very quick and fair peer-review system, which is all easy to use. Visit http://www.dovepress.com/testimonials.php to read real quotes from published authors. 